on account of war service. Arrangements have again been made to keep the awards open for those now engaged on national duties so as to allow their researches to be resumed at a later date. Further, if a fellow or scholar has undertaken Government work within the universities, he is allowed by the Trust to do so subject to a certificate being obtained from the principal of the university for a fellow or from his supervisor for a scholar to the effect that the work is of that nature. Reference is made to work by Dr. Walter Tebrich under his fellowship in organic chemistry in collaboration with Dr. W. O. Kermack on compounds related to the sulphanilamide drugs, leading to many new pyridine and piperazine derivatives, and on the discovery of new antimalarials, involving syntheses in the benzcarbazole series. In connexion with grants to assist investigations in organic chemistry the report refers to work on derivatives, of acridone related to the sulphanilamide drugs, and to work on the polysaccharides of ribwort seeds and of Irish moss. The report of the superintendent of the Laboratory of the Royal College of Physicians, in addition to further reference to the work of Dr. Tebrich, also refers to other work on antimalarials carried out by Dr. A. P. Weatherhead and by Mr. W. Webster on the synthesis of phenanthroline compounds derived from $m$-phenylenediamine.

\section{Zoos in War-time}

The annual report of the Zoological Society of London, presented at the annual meeting on April 29, shows that, despite a drop of about half the income and attendance figures down to about a third of the normal gate, some two thousand animals have been maintained at Regent's Park, and it is intended to maintain the zoological collection until full activities can be resumed after the War. In 1940 seventy. eight mammals, including an onager, fifty-five birds, and twenty-four reptiles were bred at Regent's Park, and two Rheinhardt's argus pheasants have been reared. Damage from more than 120 fire and explosive bombs has been less than expected, only the rodent house and zebra and wild ass house being seriously damaged, and the young giraffe, 'Boxer', bred at Whipsnade, died of a dilated heart due to overexertion caused by fright. A few antelopes died of damage caused by fright. Damage to the monkey hill, camel house, ravens' aviary, aquarium and north gate can be made good, while bomb craters at Whipsnade can be relined to serve as dew ponds. The work of the prosectorium is being continued, with the usual examination of blood parasites and bacterial flora, research on the protozoan and helminth parasites of fish, and the routine examination of animals for helminth ova to facilitate preventive measures.

The report of the North of England Zoological Society shows the increasing receipt of animals from other zoos like Bristol, Dudley and Edinburgh to its zoological gardens at Chester for the duration of the War, and of special war-time feeding successes, notably waste chicken heads for leopards and lions, horse-flesh for pelicans, and dried, crumbled stale bread for cranes and pheasants, porridge for sun bears. In the difficulty of losing its male keepers for the services, this Society has had disappointing results from the appointment of girl keepers. The griffin vulture was bred for the first time in Great Britain, and the young bird is now thriving: the adults laid again on March 19.

\section{American Message to British Zoologists}

AMERICAN men of science are not forgetful of their colleagues in Great Britain, and many letters expressing interest in conditions in Great Britain tell of the concern they feel. The American Society of Zoologists has expressed its goodwill in the following cablegram, received by the President of the Association of British Zoologists (Prof. J. Ritchie): "The American Society of Zoologists recently in session at Philadelphia sends greetings and encouragement to its British colleagues. I. V. Domm, Secretary". Needless to say, British zoologists warmly appreciate this friendly message, and look forward to a reunion in Great Britain with their American friends when, as J. B. Priestley suggested, the streets shall be blazing with light and all the windows shall be illuminated-but not through the agency of incendiary bombs.

\section{Agricultural Meteorology in India}

A FAIRIY detailed account of a year's research work in agricultural meteorology is to be found in the official annual report of the Agricultural Meteorological Section, India Meteorological Department, for the year, 1938-39 (Pp. vi +48 . Simla : Government of India Press, 1940). The Imperial Council of Agricultural Research again financed the section, although proposals for making the Section permanent were under consideration by the Government of India. The Central Agricultural Meteorological Observatory, which is situated in the grounds of the Agricultural College, Poona, extended the scope of its work. This was made possible through the gift of an additional plot of land to the Observatory by the College. Experiments were continued at the Observatory on the rate of ascent of moisture through typical soils and its rate of evaporation from their surfaces. A 30 - $\mathrm{ft}$. tower was erected on the new plot for the investigation of variations with height of wind, humidity and temperature. Instrumental development included the design of an instrument for measuring the amount of rain or irrigation water lost by evaporation and by percolation and that actually retained in those layers of the soil with which plants are concerned. A few instruments of this design were made and preliminary trials of them begun.

'Precision' observations for showing the effect of weather on certain crop yields were continued at Poona and Karjat, and trials of statistical methods of sampling for the estimation of crop yields were made. Statistical investigations were also continued of a number of other subjects which have particular importance for agriculture apart from their general 
meteorological interest, among them being that of the date and type of the onset of the south-west monsoon along the west coast of India and of the evidence for the influence of afforestation on climate in the Singhbhum District. A notable result of the Section's activity in liaison between meteorology and agriculture can be seen in Appendix I of this report, which is a long list of experimental farms at which meteorological instruments have been installed, with details of each lay-out.

\section{Timber Utilization in Malaya}

Malayan Forest Records No. 13 (Caxton Press, Ltd., Kuala Lumpur, 1940), by H. E. Desch and A. V. Thomas, is not intended to replace the standard text-books, but to provide local timber users with a minimum of information necessary for the correct use of Malayan timbers under Malayan conditions. The paper, which is fully illustrated, deals with the subject on the well-known lines of : anatomical structure of wood, identification and classification of Malayan timbers, seasoning, defects, preservation, mechanical properties of timber, and design in relation to correct utilization of timber in new buildings. The authors have commenced their work by giving an account of the forest administration, climatic factors, types of forest, timber resources and forest policy of Malaya, sylvicultural operations, timber requirements of the future, exploitation, methods of extraction, and financial aspects--somewhat unusual information to find incorporated in what is admittedly a handbook for timber users. The authors make a noteworthy admission. As a result of their investigations-and they have had predecessors in India-they state that in connexion with the tropical and semi-tropical forests it is not possible to draw a hard-and-fast line between the commercially productive and the protection forests; nor is it possible to calculate with any degree of accuracy the potential annual production of timber to be obtained from these types of virgin forest. The volumes per unit of area obtainable from the latter bear no relation to an equivalent area of commercial forest in temperate regions.

\section{Protection of Buried Electrical Cables}

Is the Bell Laboratories Record of January, Mr. R. P. Ashbaugh describes how the lead sheath of a buried electric cable can be protected against soil corrosion. These buried cables have been used extensively in rural areas instead of aerial cables for several years. In several localities in the United States, cases have frequently occurred where small rodents such as gophers have gnawed the cables, puncturing the sheath and so letting in moisture, which ruins the insulation. Two layers of substantial steel tape protect the cable conductors against inductive interference from power lines and also against gophers, but they are expensive, and a cheaper construction was therefore sought. The construction adopted consists of a single overlapping layer of impregnated paper, a single layer of thin steel tape applied helically with just sufficient gap to allow for normal bending, a second overlapping layer of impregnated paper, and one or two layers of impregnated jute roving. Floodings of asphalt compounds are applied over the sheath and over each protective layer of paper and jute. About 130 miles of this new construction has been furnished for the buried portion of the Stevens Point - Minneapolis cable, and a considerable number of small orders for territories that are gopher-infested have also been manufactured and installed.

\section{The Stockholm Technical Museum}

The Tekniska Museet of Sweden has recently been installed in new buildings in Stockholm, erected with funds provided by the Knut and Alice Wallemburg Foundation. The Museum was originally opened in 1923, and it has been assisted by many industrial companies and private persons. In view of the important contributions to engineering, metallurgical and chemical progress by many eminent Swedes, the Museum should prove a worthy addition to such institutions. There will be a Hall of Fame and in this will be the busts of Polhem, Swedenborg, Celsius, Angström, Rinman, John Ericsson, Carlund, Nobel, De Laval, Wenstrom, Brinell and others. An outstanding exhibit is an original tower clockwork shown running, designed and built by Polhem. It was moved to the Museum from St. Mary's Church in Stockholm, where it had been running from 1765 until 1910.

\section{Vital Statistics of London County Council}

The interim report of the London County Council Medical Officer of Health and School Medical Officer for the year 1939 contains the following information : The residential population for the middle of 1939 was $4,013,800$, as compared with $4,062,800$ at the middle of 1938 . The marriages registered in London during 1939 numbered approximately 54,461, or $27 \cdot 1$ persons married per thousand of the population. The live births allocated to London during 1939 were approximately 52,366 , as compared with 54,495 in the previous year. The live birth-rate was 13.0 per thousand, the rate for 1938 being $13 \cdot 4$. The deaths in the total population of London during 1939 numbered 46,377, giving a death-rate of $12 \cdot 3$ per thousand, as compared with 11.4 in 1938. Of the total deaths 22,554 , or $48 \cdot 6$ per cent, were among females. There was an increase in the number of fatal street accidents-from 363 in 1938 to 519 in 1939. The deaths under one year of age per thousand live births were 47 , compared with 57 in the preceding year. This constitutes a new low record.

\section{Dr. Heinrich Kisch}

Dr. ENoch Heinrich Kisch, an eminent balneologist and gynæcologist, was born on May 6, 1841, at Prague, where he received his medical education and qualified in 1862. In the following year he settled in Marienbad as a balneologist, and largely contributed to making that town a health resort. In 1867 he was appointed lecturer, and in 1884 extraordinary professor in balneotherapy, at the medical faculty of Prague. In 1868 he became editor of the Allgemeine balneologische Zeitschrift, and later of the Jahrbïcher 